\title{
Lokalizált agresszív parodontitisben szenvedő páciens komplett fogászati ellátása
}

\author{
Esetismertetés
}

\author{
DR. NAGY ZSOLT, DR. NEMES JÚLIA, DR. NYÁRASDY IDA
}

\begin{abstract}
34 éves férfi páciens konzerváló fogászati ellátásra jelentkezett klinikánkon. Részletes anamnézis és a fogászati vizsgálat során parodontális kórkép került felismerésre. Az intraorális vizsgálat kiterjedt a cariologiai és parodontális státusz felvételére. A fogágy tapadási nívójának mérése, az anamnesztikus adatok, illetve röntgenleletek birtokában lokalizált agresszív parodontitis (LAP) került diagnosztizálásra. A komplett kezelési tervbe történő beleegyezése után átfogó fogászati prevenció, terápia és rehabilitáció történt. A kezelések instruálással, motiválással, majd supra- és subgingivális depurálással kezdődtek. Később extractio és elektív gyökérkezelés után mútéti nyitott kürettel egybekötött hemisectio történt. A szükséges tömések elkészülte után fix fogpótlásokkal lett a funkció és az esztétika definitíven helyreállítva.

Az eset rámutat, hogy a rendelőbe érkező pácienseknél kiemelkedő jelentőségű a fogazati állapot felmérése mellett a parodontium vizsgálata is, hiszen enélkül a sokszor panaszmentes betegség rejtve maradhat.
\end{abstract}

Kulcsszavak: LAP, oki parodontális terápia, kontroll

\section{Bevezetés}

A lokalizált agresszív parodontitis egy jelentős tapadásveszteséggel és csontpusztulással járó parodontális kórkép. Az elmúlt évszázadokban ezt a kórformát különböző névvel említette az irodalom. Mivel ínygyulladás alig társul hozzá, hosszú ideig degeneratív jelenségnek vélték, és „parodontosisnak” nevezték. Az 1970-es évektől lokalizált juvenilis parodontitisnek (LJP) nevezték [1]. Prevalenciája igen alacsony, epidemiológiai vizsgálatok szerint sehol nem éri el az 1\%-ot. Az afro-amerikai lakosság körében hétszer gyakrabban fordul elő, mint a kaukázusi lakosság körében. Általában a pubertás körül kezdődik, és jellemzője, hogy leggyakrabban a középső metszők és az első molaris fogak érintettek, itt alakul ki jelentős tapadásveszteség, valamint verticális csontpusztulás [4]. A folyamat lokalizált jellege régóta ismert tény, de pontos magyarázata még ma sem ismert. Több elmélet is született, ezek közül a legkézenfekvőbb magyarázat szerint a szájüregben legkorábban megjelenő két permanens fogcsoportban, az első molarisok és a középső metszők körül kialakuló ínybarázdát fertőzi meg az egyébként arra fogékony szervezetben az Aggregatibacter actinomycetemcomitans. Irodalmi adatok szerint a baktérium jelenléte a tasakban primer etiológiai tényező. Lokalizált agresszív parodontitisben szenvedő páciensek $97 \%$-ának tasakjából kitenyészthető, szemben a krónikus parodontitissel, ahol ez a szám csupán $21 \%$. Az aktív tasakokban igen magas a bak- térium csíraszáma, míg ugyanannak a betegnek az ép sulcusában egyáltalán nem, vagy csak kis számban található meg a kórokozó [2, 9]. A betegség hátterében jól definiálható szervezeti rezisztenciazavarok is kimutathatók. A szérumban és a sulcusban jelentős menynyiségú ellenanyag mutatható $\mathrm{ki}$, a baktérium azonban többnyire rezisztens a bakteriolitikus folyamatokkal szemben [13]. Az Aggregatibacter actinomycetemcomitans elleni védelemben a fő szerep a PMN-leukocytáké. A betegek $75 \%$-ban azonban valamilyen PMN-leukocytazavar mutatható ki [9]. Ezen sejtek membránján csökkent az IgG-proteinkötő receptor expressziója, ennek révén gyenge a különböző kemotaktikus ingerekre adott válasz is. A PMN-leukocyták transendothelialis diapedesise, szövetközti migrációja és fagocitálóképessége csökkent értékü. Ennek oka lehet a neutrophil receptor expresszió genetikus hibája, vagy bizonyos citokinek túlfokozott termelése, melyek a felszíni membrán receptorok expressziójának gátlását okozzák.

A szervezetben magas szisztémás humorális immunválasz alakul ki, és a specifikus IgG megakadályozza a később előtörő fogak körüli sulcus fertőződését, ezáltal a folyamat generalizálódását. Az elméletet támasztja alá, hogy lokalizált agresszív parodontitises páciensek plakk baktériumai ellen magas keringő ellenanyag titer mutatható ki [2, 9]. A parodontitist leszámítva jellemző, hogy a páciensek általában egészségesek. A betegség klinikai képéröl elmondható, hogy a páciensek supragingivális szájhigiénéje jó, alig található tapadó plakk és 


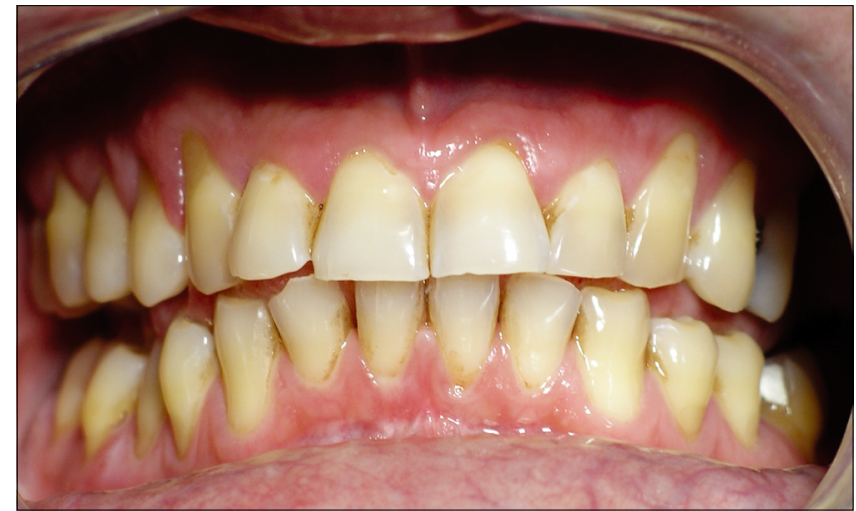

1. kép: Kiindulási állapot

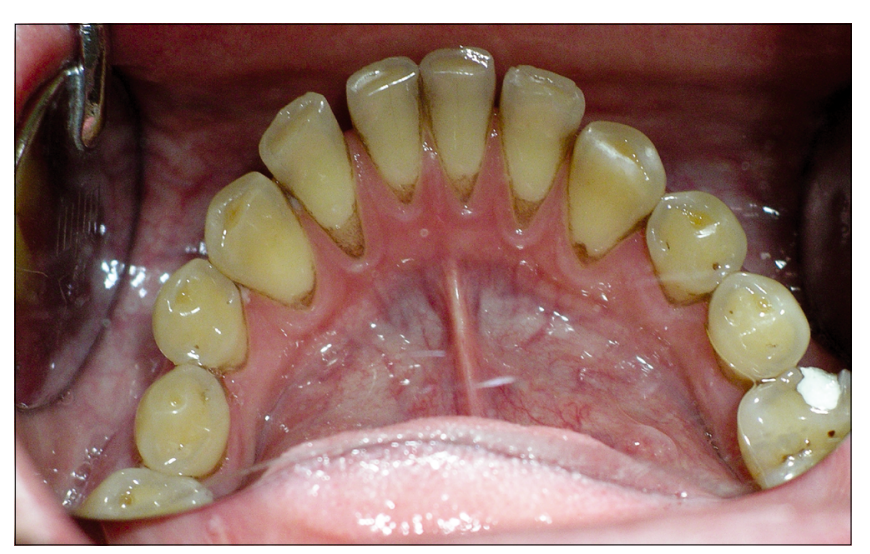

2. kép: Kiindulási állapot

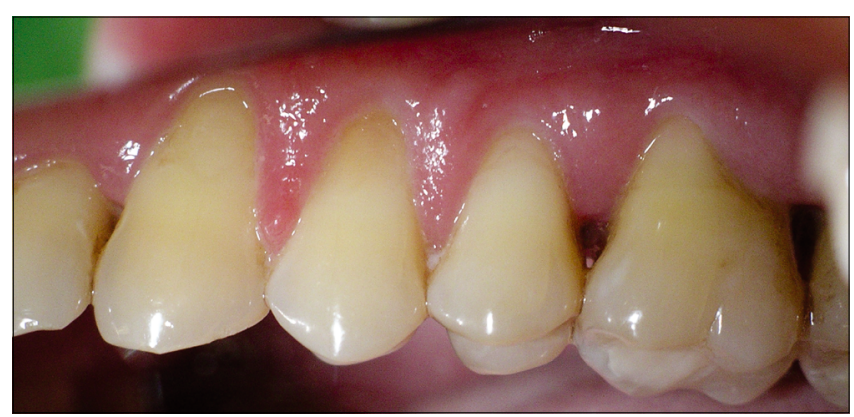

3. kép: Kiindulási állapot

supragingivális fogkő. A klinikailag értékelhető szájhigiéné foka, a lokális irritatív tényezők és a betegség súlyossága között nincs pozitív korreláció. A plakk legfeljebb csak nagyon vékony biofilmet alkot a fogakon, és ez ritkán mineralizálódik. A fogak általában cariesmentesek. Az elváltozás első tünete lehet egy parodontális abcessus kialakulása. Az ínyszél nem, vagy csak alig gyulladt, de az érintett fogak a helyükről elvándorolhatnak, erős mobilitást mutatnak, és szondázáskor jelentős szondázási mélység regisztrálható. Ilyenkor a tasakból vér és gennyes váladék ürülhet $[4,5,6,11]$. Az érintett fogak radiológiai képén mély tölcsér alakú csonthiány látszik, míg a többi fog mellett a parodontális csontállomány megtartott. Gyakori a második premoláris distalis gyökérfelszínétől kiinduló, az első nagyörlőt körbeölelő és a második nagyörlő mesialis felszínéig terjedő cirkuláris tölcsérszerü csontlaesio [5, 11]. Lokalizált agresszív parodontitis esetében kiemelkedő fontosságú követni a komplex parodontális terápia 4 fő szakaszát [3]. Az első szakasz során a betegséget kiváltó tényezők eliminálása, a fogágy gyulladásának megszüntetése (1., 2., 3. kép) és a betegség további progressziójának megakadályozása a cél [8]. LAP esetén mechanikus oki terápia (supra- és subgingivális depurálás és gyökérsimítás) mellett kiemelkedő hangsúlyt kaphat a szisztémás antibiotikus terápia a parodontopatogén komplexek eliminálása végett. Az Aggregatibacter actinomycetemcomitans baktérium eliminálásához metronidazol terápiát szükséges kombinálni amoxicillinnel [14]. Természetesen a lokális plakkretenciós tényezők eliminálása, a szájhigiéne fejlesztése és a hipermobilis fogak sínezése is elengedhetetlen az oki terápia során. A második szakaszban következik a korrekciós parodontális terápia, úgymint a regeneratív és mucogingivális mútétek. A harmadik szakaszhoz tartozik a parodontitisben elvesztett fogak perioprotetikai rehabilitációja. Végezetül az utolsó szakasz a páciens rövid és hosszútávú utógondozása rendszeres kontrollvizsgálatokkal és fenntartó kezeléssel [8].

\section{Esetismertetés}

34 éves férfi páciens 2008 márciusában érkezett klinikánkra 36 fogának zománcfraktúrájával. Akut panasza nem volt. Általános anamnézisében ájulásra való hajlam szerepelt, szisztémás betegségben nem szenved, gyógyszereket nem szed, nem dohányzik, fogászati anyagokkal szembeni allergiája nincs. Jelentkezése előtt 5 évig az USA-ban élt, ahol évente vett részt kontrollvizsgálaton. A páciens jó szájhigiénével rendelkezett, elmondása szerint naponta $2-3 \times$ mos fogat, valamint rendszeresen öblöget szájvízzel. A stomato-onkológiai szűrés során elváltozást nem találtam. A temporomandibuláris ízület vizsgálata során diszfunkció nem jelentkezett. A nyálmirigyek tapintásakor sem fájdalmas pontot, sem duzzanatot nem találtam, a ductusokból nyomásra víztiszta nyál ürült.

\section{Fogazati státusz}

Az 16. és 17. fogakban I. osztályú kompozit tömés található, melyek 2 éven belül készültek. Mindkét fog vitálisnak bizonyult, széli záródásuk tökéletes, elszíneződve nem voltak. A 24. fogban II. osztályú OD, a 25. fogban II. osztályú MO amalgámtömés készült. Mindkét premolaris vitális volt, mellettük secunder caries volt megfigyelhető. A 25. fog tömésszéle approximálisan túlkonturált, elálló. Az alsó állcsont fogai is megtartottak, a 36. fogon mesiobuccálisan kismértékü 
zománcfraktúra volt látható, caries következtében. Okklúziós analízist végeztem a páciensnél artikulációs papírral mely nem mutatott korai érintkezési pontot, kiegyensúlyozott volt, harapási formája eugnath (1., 2., 3. kép).

\section{Parodontális státusz}

Ezután került sor a páciens parodontális vizsgálatára. Az ínyrecesszió fokát és a tasak klinikai szondázási mélységét milliméter beosztású parodontális szondával (UNC 15 Stoma, Tuttlingen, Németország) végeztem. Az íny a felső molarisok tájékán mindkét oldalon szondázásra vérzett. Felvettem az ínyvérzési indexet a fogak 6 felszínére vonatkoztatva, mely $32 \%$ lett. Ezt követően a szondázási mélységet és a furcatio érintettséget regisztráltam, melyhez egyéni szerkesztésú táblázatot és diagramot készítettem (4. ábra). A 16. és 17. fog esetében elsősorban a buccalis oldaIon jelentős tapadásveszteséget, néhol $8 \mathrm{~mm}$-es tasakmélységet mértem. A parodontitis következtében kialakult ínyrecesszió mértéke nem haladta meg a $2 \mathrm{~mm}$-t Mindkét fog a buccalis gyökerek között III. fokú furcatiolaesióval rendelkezett, mozgathatók nem voltak. A 26. fog vizsgálatakor rendkívül mély, $10 \mathrm{~mm}$-t meghaladó tasakmélységet szondáztam, a csontpusztulás cirkulárisan az apicalis régióig terjedt, a fog mozgathatósága III. fokú volt [12]. Az alsó és felső állcsont további fogai körül jelentősebb ínyrecesszió volt megfigyelhető, gyulladásmentes marginális gingivával, így vélhetőleg nem parodontális eredetű, hanem egyéb okokra vezethető vissza, mint a vékony gingiva fenotípus, buccalis csontdehisztenciák, vagy a helytelen fogmosási technika. [5]

\section{Radiológiai vizsgálat}

A klinikai vizsgálat után orthopantomogram készült, valamint teljes röntgenstátusz periapicális felvételekkel. Az említett tapadásveszteséget leszámítva a páciens többi fogán elváltozás nem volt tapasztalható. A temporomandibuláris ízületi felszínek épnek, a sinus és az orrüreg tisztának bizonyultak. Az állcsontokban egyéb elváltozás nem látható (5. kép). A páciens parodontális betegségének gyanúját a röntgenvizsgálat alátámasztotta. A parodontális vizsgálat és a röntgenanalízist követően felállított diagnózis valószínűsíthetően lokalizált agresszív parodontitis. Az érintett fogak megállapított vitalitása kizárta az esetlegesen felmerülő endo-parodontális lézió, illetve verticális gyökérfraktúra kórképeket.

\section{Kezelési terv}

1. Supra és subgingivális depurálás. A páciens szájhigiénés instruálása és motiválása során a megfelelő fogmosási technika elsajátítása, valamint fogköztisztító kefe alkalmazásának javaslata.

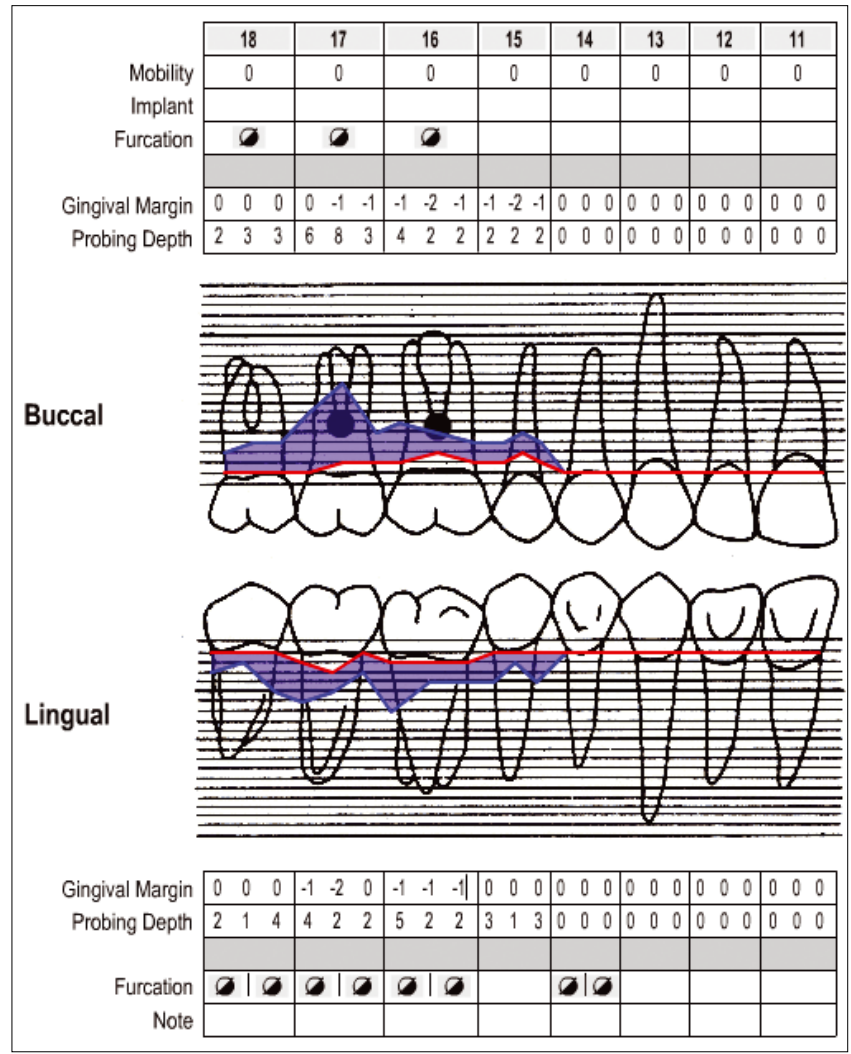

4. ábra: Ínyrecesszió és szondázási mélység felvételkor

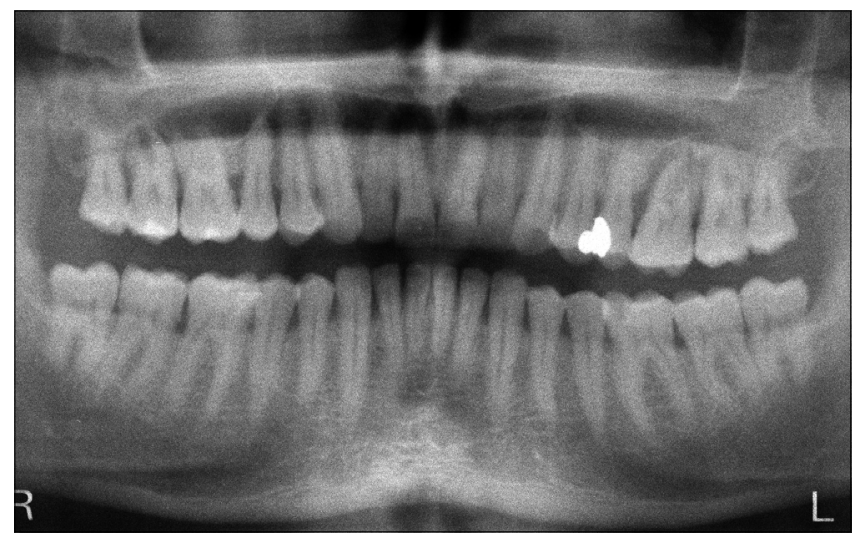

5. kép: Radiológiai státusz (OP)

2. A 26. fog extractiója.

3. 16. és 17. fog gyökérkezelése.

4. Az 16. fog distobuccalis, az 17. fog mesio- és distobuccalis gyökerének mútéti eltávolítása nyitott kürett során.

5. A 24. és 25. fogakból az amalgámtömések eltávolítása és kompozit tömések készítése. A 36. fog szuvas laesiójának feltárása és kompozit töméssel való ellátása.

6. A 16. és 17. fogakra ideiglenes, majd végleges fémkerámiasín készítése. A 25. és 27. pillérfogakra először ideiglenes, majd végleges fémkerámia-hídpótlás készítése. 


\section{Kezelés folyamata}

Az első beavatkozás alkalmával supragingivális depurálást végeztem, valamint az instruálás, motiválás során a páciens megtanulta az interdentális kefe használatát. Ekkor a felső fogívről szilikonlenyomatot (Zeta Plus, Zermack) vettem, melyet később provizórikus pótlás készítésére használtam fel. Egy hét elteltével subgingiválisan kürettáltam az 16. és 17. fogakat, és eltávolítottam a 26. fogat, menthetetlen prognózisa miatt [10, 12]. A kö-

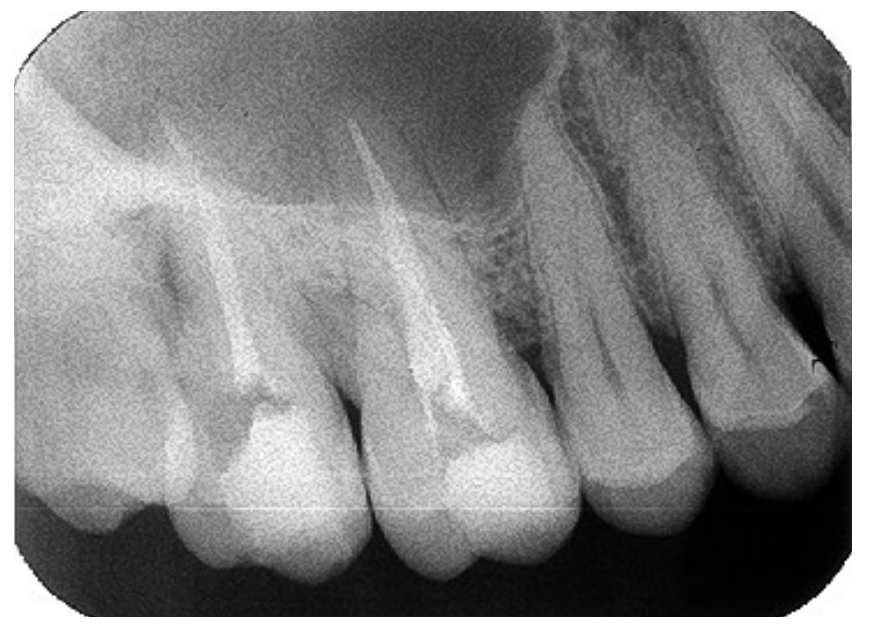

6. kép: Periapikális kontroll röntgenfelvétel gyökérkezelés után

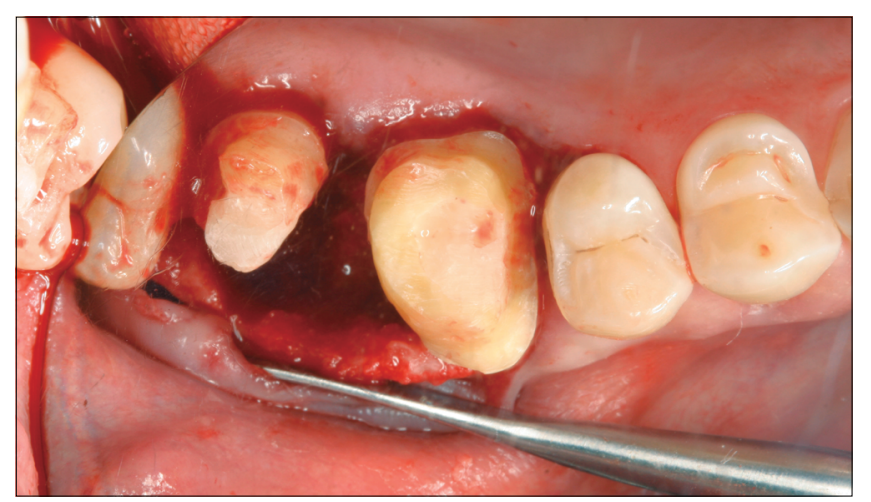

7. kép: Nyitott kürett mútét

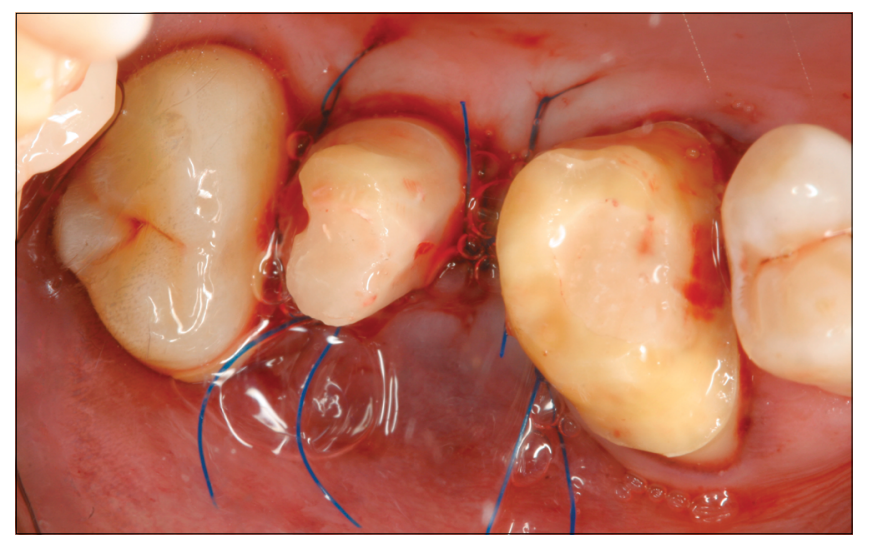

8. kép: Sebszélek zárása vetkező kezelés során kofferdam izolálásban elvégeztem az 16. és 17. fogak gyökérkezelését elektív okból, melyet a betervezett hemisectio indokolt. A trepanálást és exstirpálást követően csak a fogak később megtartandó gyökereinek csatornáit tágítottam fel és láttam el gyökértöméssel, a többi gyökércsatornába $\mathrm{Ca}(\mathrm{OH})_{2}-$ pasztát helyeztem (6. kép). A parodontális kezelési terv alapján megtartandók voltak a 16. fog palatinális és mesiobuccális, a 17. fog palatinális gyökerei [5]. A gyökértömések elkészülte után a trepanációs nyílásokat hosszú távú ideiglenes tömésként üvegionomer cementtel (Ketac ${ }^{\mathrm{TM}}$ Molar Easymix, 3M ESPE) zártam. A következő alkalommal történt a 16. és 17 . fog supragingivális vállas csonkelőkészítése és a parodontális nyitott kürett mütét, melynek során lebenyképzést követően eltávolításra került a fent említett három gyökér, valamint a még fennmaradó subgingivális fogkő és gyulladásos szövetek. A sebszélek varratokkal lettek egyesítve (7., 8. kép). Egy hét elteltével következett a mútéti kontrollvizsgálat és a varratok eltávolítása (9. kép), továbbá ideiglenes koronák készítése a mútött fogakra Scutan módszerrel (Structur 2 SC, A3, VOCO). A teljes mútéti és extractiós sebgyógyulásig hátralévő idő alatt készültek el a tervezett kompozíciós tömések, így a 24. fogban II. osztályú OD, a 25. és 36 . fogakban pedig II. osztályú MO restaurációk (Filtek ${ }^{T M}$ P60, A3, 3M ESPE). Egy hónap elteltével következett a mútéti kontroll, melynek során az íny egészségesnek bizonyult, vérzés nem volt tapasztalható, a tasakmélység sehol nem haladta meg a $3 \mathrm{~mm}$-t (10. ábra). A gyógyultnak tekinthető parodontium lehetővé tette a protetikai rehabilitációt $[7,8]$. A 25. és 27. fogak előkészítése supragingivális vállal történt, ezt követően kétfázisú kétidejü precíziós-szituációs lenyomat (Zetaplus - Oranwash L, Zhermack) készült mind a négy csonkról, valamint lenyomat az antagonista fogívről alginát lenyomatanyaggal, és a centrális okklúzió meghatározása viaszharapás segítségével. Ideiglenes hidat készítettem Scutan módszerrel a 25. és 27. pillérfogakra. A következő terminusra a fogtechnikai laborból a fémkerámia pótlások vázpróbáját kértem, melyeknek ellenőrzése először a mintán, majd a szájban történt meg. A páciens egyetértésével kivá-

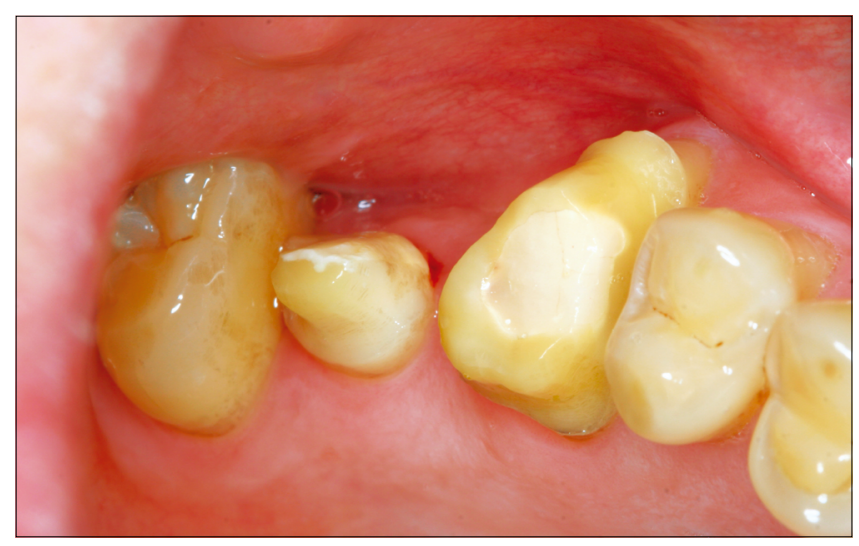

9. kép: Kontroll mütét után 


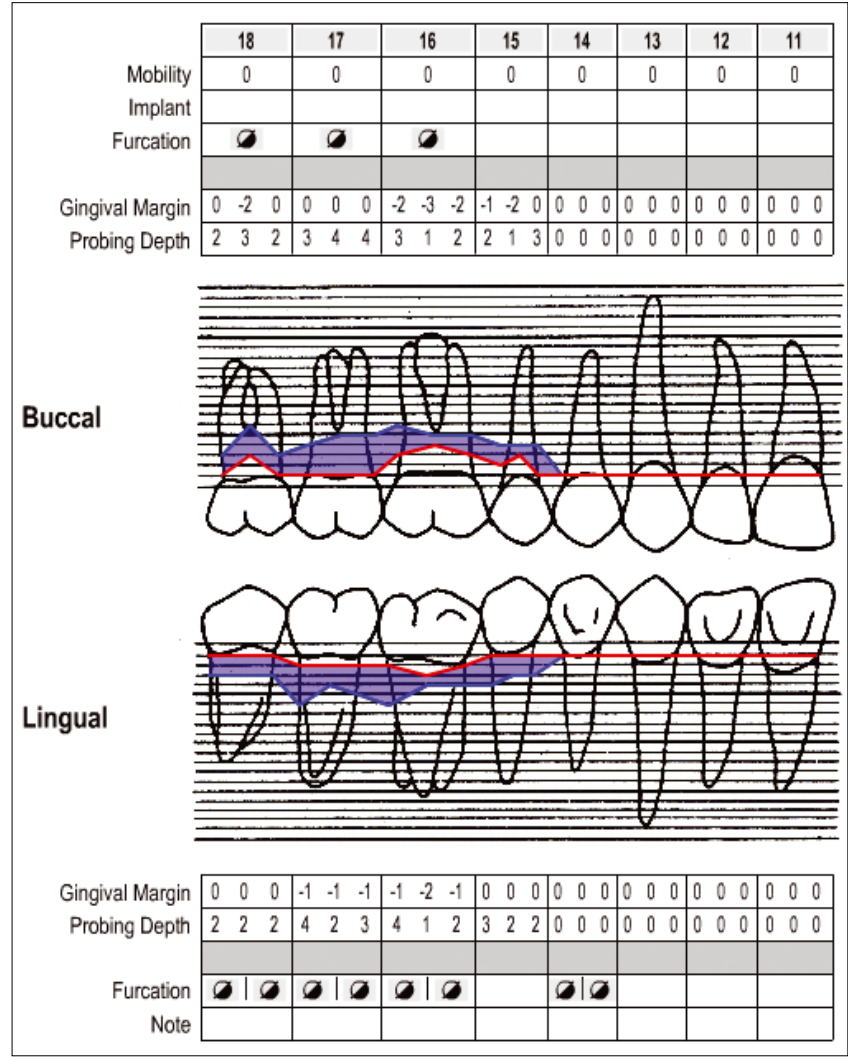

10. ábra: Ínyrecesszió és szondázási mélység az oki parodontalis terápia után

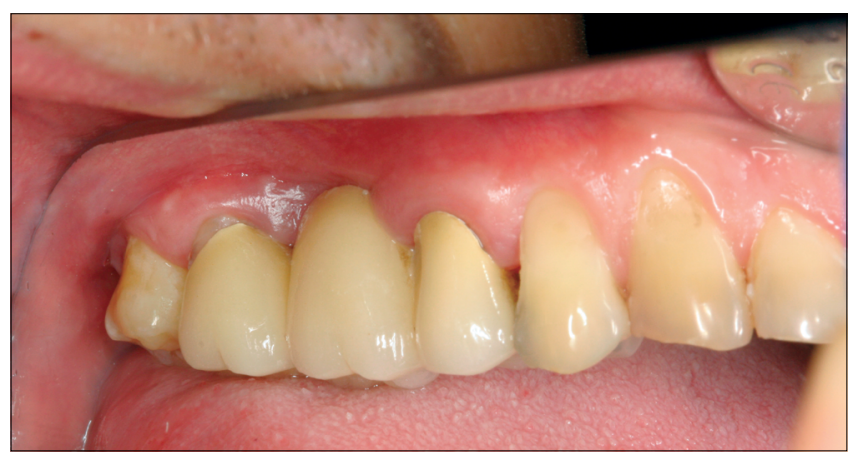

11. kép: A kész fix fogpótlások

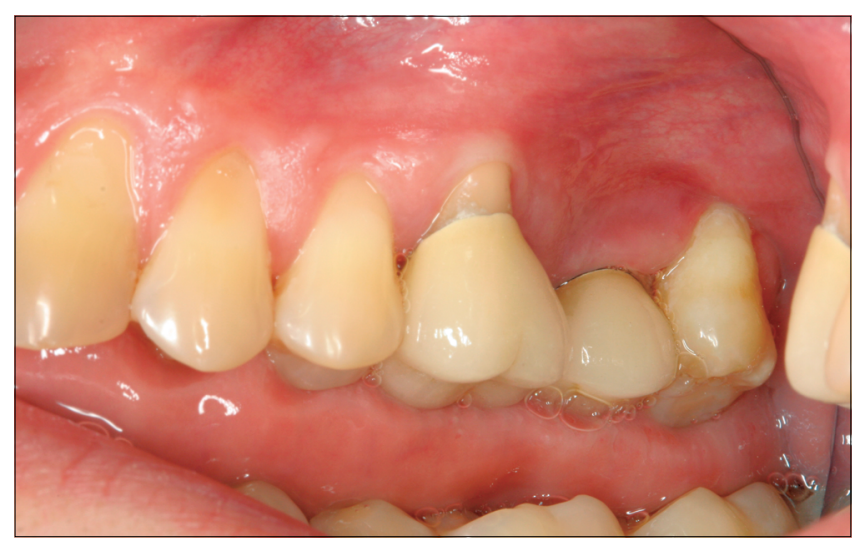

12. kép: A kész fix fogpótlások lasztott, megfelelő fogszínnel (Vita A3) a kontroll során pontosnak talált vázak kerámiával leplezésre kerültek. A pótlások véglegesen kerültek rögzítésre üvegionomer ragasztócementtel (Ketac ${ }^{\mathrm{TM}} \mathrm{Cem}, 3 \mathrm{M}$ ESPE) (11., 12. kép). A páciens az átadás alkalmával megtanulta a fogköztisztító kefe és a superfloss megfelelő lokális alkalmazását. Egy hét elteltével került sor az első kontrollvizsgálatra, ahol a pótlás korrekciójára nem volt szükség, a páciens a fogpótlást elégedetten viselte, rágáskor mindkét oldalát egyenrangúan tudta használni. Kontrollvizsgálatokra félévente kerül sor, melyek során a szájhigiénés állapot, a fogak és a parodontium állapota kerül regisztrálásra.

\section{Megbeszélés}

A lokalizált agresszív parodontitis az európai lakosság körében egy ritkán előforduló, ám a krónikus parodontitistől jól elkülöníthető kórforma. Fontos a betegség mielóbbi diagnózisa, hogy az LAP progresszióját minél korábbi stádiumban megakadályozzuk. A választott terápia is nagyban függ a betegség előrehaladottságától és a lokalizált csontpusztulás mértékétől [11]. Az érintett fogak extractiója mindig csak végső ellátási alternatíva lehet, előnyben kell részesíteni a parodontális sebészi módszereket és az ezt követő rendszeres kontrollvizsgálatokkal egybekötött professzionális szájhigiénés kezeléseket [8]. Természetesen a kezelés sikerét hoszszú távon jelentősen befolyásolja a páciens hozzáállása. A parodontális betegségek kezelése a páciensek részéről türelmet és szorgalmat igényel, melyhez nélkülözhetetlen a kezelőorvos motiváltsága és empátiája.

\section{Irodalom}

1. Armitage GC: Development of a classification system for periodontal diseases and conditions. Ann Periodontol 1999; 4: 1-6.

2. DenNinson DK, VAN DYKE TE: The accute inflammatory response and the role of phagocytic cells in periodontal health and disease. Periodontol 2000; 14: 54-78.

3. Gera I: Parodontológia. Semmelweis Kiadó, Budapest, 2005; 201210.

4. Greenstein G, Lamster I: Understanding diagnostic testing for periodontal diseases. J Periodontol 1995; 66: 659-666.

5. Halazonetis TD, HafFaJee AD, Socransky SS: Relationship of clinical parameters to attachment loss in subsets of subjects with destructive periodontal diseases. J Clin Periodontol 1989; 16: 563-568.

6. Kaldahl WB, KalkWarf KL, Patil KD, Molvar MP: Relationship of gingival bleeding, gingival suppuration, and gingival plaque to attachment loss. J Periodontol 1990; 61: 347-351.

7. Lang NP, Adler R, Joss A, Nyman S: Absence of bleeding on probing. An indicator of periodontal stability. J Clin Periodontol 1990; 17: 714-721.

8. Lindhe J, Westfelt E, Nyman S, Sokransky SS, Heisl L, Bratthall G: Healing following surgical/non-surgical treatmant of periodontal disease. A clinical study. J Clin Periodontol 1982; 9: 115-128.

9. Loesche WJ, Bretz WA, Lopatin D, Stoll J, Rau CF, Hillenburg KL ÉS MTSAI: Multi-center clinical evaluation of a chairside method for detecting certain periodontopathic bacteria in periodontal disease. J Periodontol 1990; 61: 189-196. 
10. Pattison AM, Pattison GL: Scaling and Root Planing in Carranza's Clinical Periodontology eds. Newman, Takel Carranza. 9th edition W.B. Saunders. 2002; 631-645.

11. VAN DER WeLDEN U: Diagnosis of periodontitis (Letter to the editor). J Clin Periodontol 2000; 27: 960-961.

12. Wang HL, Burgett FG, Shyr Y, RamfJord S: The influence of molar furcation involvement and mobility on future clinical periodontal attachment loss. J Periodontol 1994; 65: 25-29.
13. Kornman KS, Page RC, Tonetti MS: The host response to microbial challange in periodontits: assembling the players. Periodontol 2000. 1997 jun; 14: 33-53.

14. J Cunha-Cruz, PP Hujoel, G Maupome, B Saver: Systemic Antibiotics and Tooth Loss in Periodontal Disease. J Dent Res. 2008 sep; 87(9): 871-876.

Nagy Zs, Nemes J

\section{Complete dental care of patients suffering from localized aggressive periodontitis Case report}

A 34 years old male patient was referred to our clinic for restorative dental treatment. During detailed consultation and dental examination a relatively rare form of periodontal disease had been diagnosed. Intraoral examination included recording of dental and periodontal status. Based on patient's dental history, measurements of probing pocket depths (PPD), clinical attachment level (CAL), and also the X-ray findings, Localized Aggressive Periodontitis (LAP) unknown by the patient was diagnosed. After patient's consent the comprehensive treatment plan covered the dental prevention, periodontal non-surgical and surgical therapy and rehabilitation. The treatment started with oral hygienic instruction, motivation then supra- and subgingival scaling and rootplaning. Later extraction and elective root canal treatment were performed, followed by open flap periodontal surgery combined with hemisection of two molars. After a full mouth conservative restorative therapy, function and esthetics were restored by fix dental prostheses.

This case is a good example to underline the importance of periodontal examination during the dental screening and dental status recording for each patients showing up at dental clinics. Otherwise in many cases this asympthomatic disease can remain undetected.

Key-words: LAP, cause related periodontal therapy, control 